\title{
Ethical, pedagogical, socio-political and anthropological implications of quaternary prevention*
}

\author{
Marc Jamoullea Michel Roland ${ }^{b}$, Jong-Myon Bae ${ }^{c}$, Bruno Heleno ${ }^{d}$, Giorgio Visentine, Gustavo Diniz Ferreira Gusso ${ }^{\dagger}$, Maciek Godycki-Ćwirko, \\ Miguel Pizzanell ${ }^{\mathrm{h}}$, Patrick Ouvrardi, Ricardo La Vallej, Luis Filipe Gomesk, Daniel Widmer', Jorge Bernstein ${ }^{\mathrm{m}}$, Mariana Mariñon , Hamilton Lima \\ Wagner ${ }^{\circ}$, llario Rossip
}

a MD, PhD. Family Physician, researcher, University of Liège (ULg), Belgium; University Isalud, Buenos Aires, Argentina. marc.jamoulle@gmail.com

${ }^{\mathrm{b}} \mathrm{MD}$, PhD. Family Physician. Emeritus professor of family medicine, Free university of Brussels (ULB). President of Médecins du Monde, Belgium. michel.roland@ ulb.ac.be

${ }^{c} \mathrm{MD}, \mathrm{PhD}$. Professor of preventive medicine, Jeju National University, South-Korea. aquopura@gmail.com

${ }^{d}$ MD, PhD. Family doctor, Lumiar Health Center. Assistant Professor, New University of Lisbon, Portugal. bruno.m.heleno@gmail.com

e MD. Family Physician, Specialist in emergency medicine. Centro Studi e Ricerche in Medicina Generale. Milan, Italy. visenting@gmail.com

${ }^{\dagger} \mathrm{MD}, \mathrm{PhD}$. Family Physician. Professor of primary care and family medicine at University of São Paulo, Brazil. gustavo.gusso@usp.br

${ }^{9}$ MD, PhD. General Practitioner, Professor, Centre for Family \& Community Medicine, Division of Public Health, Faculty of Medical Sciences, Medical University of Lodz, Poland.maciekgc@uni.lodz.pl

${ }^{\mathrm{h}}$ MD, MSc. Family Physician, Assistant professor of Family and Community Medicine, University of the Republic (UDELAR), Florida, Uruguay. President of the Special Interest Group of WONCA on Quaternary prevention and overmedicalization. miguelpizzanelli@gmail.com

'MD. Family Physician, Director of research of the French society for teaching in Medicine (SFTG). Paris, France. Vice-president of European Union of General Practitioners (UEMO). patrick.ouvrard@unimedia.fr

i MD, PhD. Family physician. Department of Family Medicine. University of Buenos Aires. National University of Hurlingham. Argentina. lavayear@gmail.com

k MD, PhD. Family Physician. Emeritus professor of Family Medicine, Faro University. Portugal. luis.filipe.r.a.gomes@gmail.com

' MD. Family Physician. Lecturer in Family Medicine, University of Lausanne. Switzerland. Vice-president of European Union of General Practitioners (UEMO). widmermed@gmail.com

${ }^{m}$ MD. Psychiatrist, president of the Quaternary Prevention Commission of the Argentine Federation of General and Family Medicine (FAMFyG), President of the Chapter of Quaternary Prevention of the Association of Psychiatrists of Argentina. Buenos Aires, Argentina. jorge.bernstein@gmail.com

${ }^{n}$ MD.MSc. Sociedad Argentina de Medicina Internal General (SAMIG). Ciudad de Buenos Aires, Argentina. marian_marino@yahoo.com.ar

${ }^{\circ}$ MD. Masters in Surgery. Family and Community Medicine, Preceptor of the residency program in Family and Community Medicine at Health Secretariat of Curitiba, Brazil. hamiltonw@uol.com.br

${ }^{\mathrm{P}}$ MA. PhD. Anthropologist, Professor, THEMA - Institute of Social Sciences, Faculty of Social and Political Sciences, University of Lausanne (UNIL), Switzerland. llario.Rossi@unil.ch

Cite as: Jamoulle M, Roland M, Bae J-M, Heleno B, Visentin G, Gusso GDF, et al. Ethical, pedagogical, socio-political and anthropological implications of quaternary prevention. Rev Bras Med Fam Comunidade. 2018;13(40):1-14. http://dx.doi.org/10.5712/rbmfc13(40)1860

\section{Funding:}

none declared.

Ethical approval:

not applicable.

Conflict of interests: none declared.

Provenance and peer review: externally reviewed.

\footnotetext{
* This paper has been published originally in French in the "Revue Médicale de Bruxelles", Sept 2018 and is reproduced here with due authorization.
} 


\begin{abstract}
The concept of quaternary prevention, resulting from a reflection on the doctor-patient relationship, is presented as a renewal of the age-old ethical requirement: first, a doctor must do no harm; second, the doctor must control himself/herself. The origin of the concept, its endorsement by the World Organization of Family Doctors (WONCA) and the European Union of General Practitioners (UEMO), its dissemination, and the debates to which it has given rise, are presented by a panel of authors from 10 countries. This collective text deals more specifically with: the bioethics of prevention, the importance of teaching Quaternary prevention and factual medicine, the social and political implications of the concept of quaternary prevention, and its anthropological dimensions.
\end{abstract}

Keywords: Quaternary Prevention; Ethics, Professional; Evidence-Based Medicine; General Practice

\title{
Resumo
}

O conceito de prevenção quaternária, resultante de uma reflexão sobre a relação médico-paciente, é apresentado como uma renovação da antiga exigência ética: primeiro, o médico não deve causar nenhum dano; segundo, o médico deve se controlar. A origem do conceito, o seu endosso pela Organização Mundial de Médicos de Família (WONCA) e a União Europeia de Médicos de Clínica Geral (UEMO), a sua divulgação e os debates a que deu origem, são apresentados por um painel de autores de 10 países. Este artigo baseia-se na bioética da prevenção, na importância do ensino da prevenção quaternária e na medicina factual, nas implicações sociais e políticas do conceito de prevenção quaternária e nas suas dimensões antropológicas.

Palavras-chave: Prevenção Quaternária; Ética Profissional; Medicina Baseada em Evidências; Medicina Geral

\section{Resumen}

El concepto de prevención cuaternaria, resultante de una reflexión sobre la relación médico-paciente, se presenta como una renovación del antiguo requisito ético: primero, un médico no debe hacer daño; segundo, el médico debe controlarse a sí mismo. El origen del concepto, su respaldo por parte de la Organización Mundial de Médicos de Familia (WONCA) y la Unión Europea de Médicos Generales (UEMO), su difusión, y los debates a los que ha dado lugar, son presentados por un panel de autores de 10 países. Este texto colectivo trata más específicamente de: la bioética de la prevención, la importancia de la enseñanza de la prevención cuaternaria y la medicina práctica, las implicaciones sociales y políticas del concepto de prevención cuaternaria y sus dimensiones antropológicas.

Palabras clave: Prevención Cuaternaria; Ética Profesional; Medicina Basada en la Evidencia; Medicina General

\section{Patient doctor relationships facing doubt and uncertainty in medical practice}

Uncertainty and the arrow of the time are points of support cited by llya Prigogyne to face the absurd of the world "In a probabilistic universe, in which different possibilities may appear". ${ }^{1}$ We will in this text make a trip between uncertainty and time line. We talk about clinical prevention, a search for reducing uncertainty in the course of time, in the context of a care relationship. Medicine is based on the patient-doctor relationship. Without relationship, there is no medicine, there is only technology.

It is good to analyze the question of doubt and uncertainty, according to the three angles of the patient, the doctor and the relationship that unites them (Figure 1).

These three elements form what is called a semantic triplet, a triplet that gives the relationship as much value as the other two elements and makes all three respond to uncertainty. An anthropological approach makes it possible to grasp this dimension. Uncertainty from the point of view of the patient $(P)$ is an existential uncertainty, related to the consciousness of being and death. The uncertainty of the physician (D), who is also a human and therefore a patient, is that of the doubt which constitutes the basis of any scientific approach. Without doubt there is no science, no questions, no medicine. 


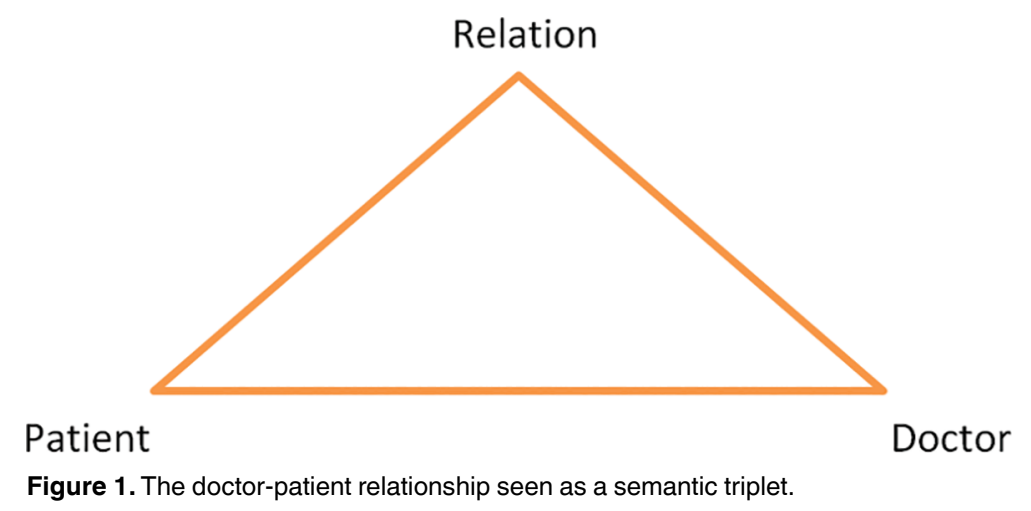

We thus see that the relation $\mathrm{R}$ is formed by the meeting of two epistemologically different points of view; existential fear and scientific doubt that can hardly coincide. It is already a difficult exercise of communication between $P$ and $D$ to agree on the contents of the relation $R$. In the theory of the communication, we will say that the channel itself generates a noise which disturbs the message. The very fact that the doctor is also a human being can strongly disrupt the relationship. ${ }^{2}$ The uncertainty of the patient will be more easily expressed if the real reason for consulting is, in a first diagnostic procedure, identified by the doctor. The patient is often more concerned with the prognosis of pain than with the pain itself. The identification of the real problem of the patient makes it possible to better answer his uncertainty.

What about the doctor's uncertainty? The answer seems obvious as the acronym EBM for Evidence Based Medicine or factual medicine indicates. As Davidof et al. argues, Evidence-Based Medicine "to fill the chasm by helping doctors find the information that will ensure they can provide optimum management for their patients" ${ }^{3}$

But situations where quantitative factual medicine may apply are rare in general practice. The data based on this medicine are often mono-pathological and technological and we know that the heart of the profession of family doctor is the qualitative and narrative approach, multimorbidity and personal care in its bio-psycho-social context. ${ }^{4}$

Considering this complexity, let's move forward into the timeline and thus into the concept of prevention.

\section{The Quaternary prevention concept, origin and dissemination}

The terms primary, secondary and tertiary prevention were coined by Leavell \& Clark in the 50', based on the phases of Syphilis model, and they have been widely disseminated in public health world..$^{5}$ This doctor-defined and disease-centered chronological view prompted Bury ${ }^{6}$ to use quaternary prevention in its chronological sense in order to define palliative care. ${ }^{7}$

We have proposed a relational vision of prevention. ${ }^{9,10}$ Our model, designed in 1986 , is built on a cross tabulation. Prevention is the result of relationships between patient and doctor over time. The cross between science and consciousness delimits four nebulae ${ }^{9,11}$ reflecting the blurred boundary between health and illness. However, in day-to-day practice, the distinction is usual and four areas of activity are represented. The timeline crosses the table obliquely. Patients and doctors meet at the end and die together (point $\Omega$ ) (see Figure 2). 


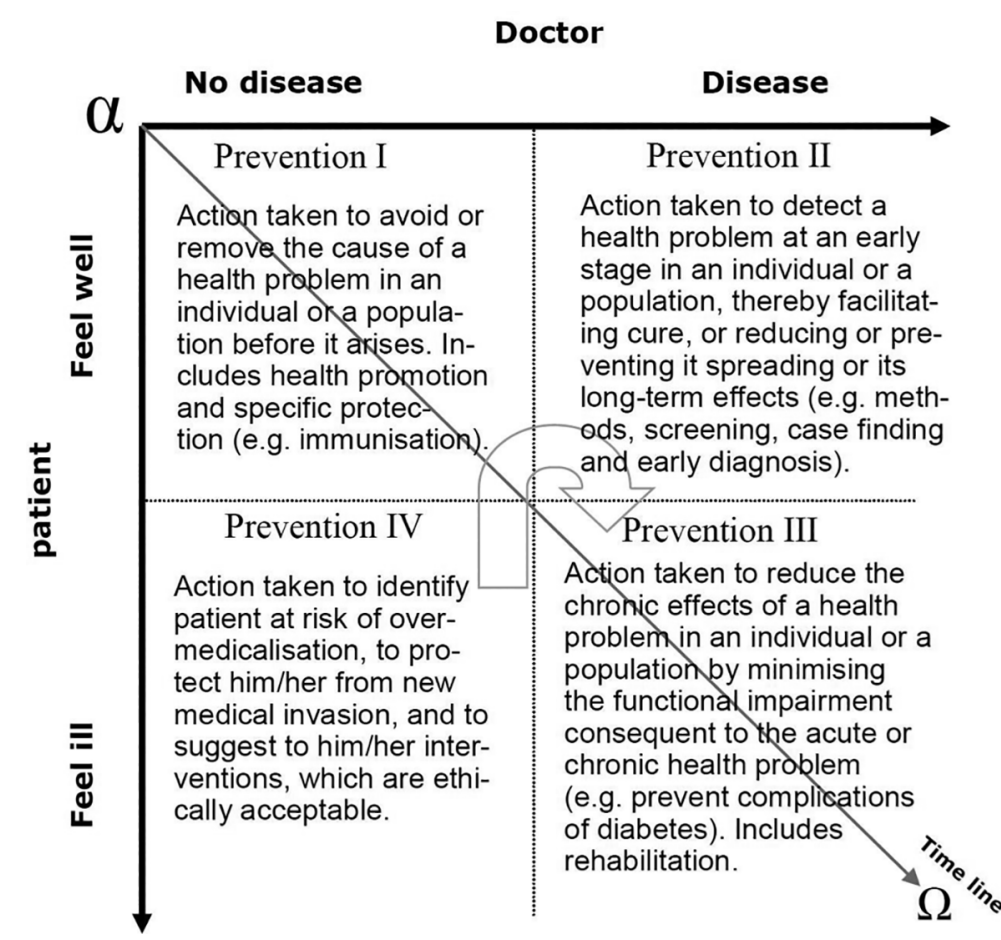

Figure 2. The four definitions of prevention (Wonca dictionary). The time line from alpha to omega shows that patients and doctors will be sick and dye together. The circular arrow shows that Quaternary prevention, converted in attitude, impacts all medical activities.

These four areas of activity form the core of family medicine. To vaccinate a healthy patient is primary prevention (true negatives). If the doctor bets on disease and offers screening, this is secondary prevention (false negatives). If the doctor make a diagnosis and the patient admits he is sick, curative medicine begins and avoiding side effects and complications and start rehabilitation is tertiary prevention (true positives).

If the patient has symptoms and the doctor cannot objectify the suffering as a disease, the suffering has no name and therefore does not exist. This illness does not find its place as a social construct. ${ }^{12}$

Putting in place a strategy that meets this denial of being is called quaternary prevention (false positives). These patients are often considered difficult and their past is often filled with violence and anxiety. They are often referred to the psychiatrist. The symptoms are sometimes the mirror of their lives. ${ }^{13}$ But there is nothing worse for a patient than to be known as a carrier of nothing. Of course, we are also talking about diagnostic errors that confine a patient to the diagnosis of fibromyalgia until ankylosing spondylitis is diagnosed.

Quaternary prevention is more than factual activity. It covers over-medicalization, over-information, over-screening, overdiagnosis, overtreatment, as well as avoidable treatments, patient protection and more generally the limits of medical care. Implicitly, patients and uncared populations are part of this area which also covers under-medicalization. Quaternary prevention also challenges these strange diagnoses as "No disease disease - clinically unexplained symptoms - worried well - heartsink or hateful patients - functional somatic syndromes - somatoform disorders - abnormal patient behavior (non-exhaustive list)." A poster translated into several languages is available on the WONCA International Classification Committee (WICC) website ((www.ph3c.org/P4). It shows the progress of the concept, its publication by WONCA in $2003^{8}$ and its approval in 2011 by the European Union of General Practitioners (UEMO). ${ }^{14}$ 
After its presentation at the 25-year Congress of the Brazilian National Unified Health System (SUS) in 2008, quaternary prevention has spread throughout Latin America. ${ }^{15}$ It also escaped from the cross-tabulation table and, applying to all areas of medicine's actions (as shown by the circular arrow in Figure 2), she became an attitude, a thought about to act the doctor himself in a relationship marked by dependency and distress.

Quaternary prevention is an ethical imperative of self-control, a renewal of the motto "primum non nocere". The movement of young South American physicians and their interest in the concept is largely due to the extremely aggressive commercialization of health by the industry. Alongside the over-medicalization that is almost intrinsic to the practice of medicine, described as positive iatrogeny by Michel Foucault. ${ }^{16}$ there is over-medicalization due to excessive commodification of health products. ${ }^{17}$ In particular, the markets for Alzheimer's, Ritalin and Hydroxycodone are in the billions of dollars. The intensive lobbying of vaccine companies and the legal requirement of certain preventive practices, such as those in Uruguay and France, raise questions. Protecting the patient against these markets has become an obligation for the doctor.

Evidence-based medicine (EBM) is a fundamental tool for deciding the right attitude, especially in pharmacotherapy, and the EBM movement seized Quaternary Prevention and reformulated its definition according to an operational vision: Measures taken to protect individuals (people/patients) medical interventions that may cause more harm than good. ${ }^{18}$

Evidence-based medicine is also important for quaternary prevention at the level of healthcare organization. One example is Poland, where the health system is based on compulsory health insurance. Physicians are paid in proportion to the number of patients on their list and are required to provide curative and preventive services. ${ }^{19}$ Of the 14 preventive interventions prescribed by the Regulation, six are not evidence-based and evidence-based medicine offers a range of interventions different from those proposed in the Regulation. ${ }^{20}$ As we point out later, this example suggests that the judicious choice of preventive interventions by the political authority is an integral part of quaternary prevention, well beyond the clinic.

Although slow, the spread of the concept has been amazing. It is translated into almost all European and some Asian languages. Following the publication of a manifesto at the WONCA conference in Rio de Janeiro in December 20160, ${ }^{21}$ a special interest group was created. ${ }^{22}$ The concept is now part of the basic teaching of family medicine. The double-entry table is particularly effective for teaching prevention. ${ }^{23}$ This reflection on the doctor-patient relationship, highlights the concerns of many family physicians around the world. Quaternary Prevention has become a movement of thought crossed by many complementary currents. ${ }^{24-27}$

Thanks to family medicine conferences and computer tools (websites, mailing lists, WhatsApp lists in many countries), exchanges have been intense. Numerous online courses and presentations have been organized, documents have been published and several adaptations of the concept have been proposed (see Table 1).

This article is the culmination of the reflections of many international colleagues. The four groups of co-authors discuss below the importance of quaternary prevention in ethical domain, its impact in teaching, the sociopolitical aspects it implies and finally the anthropological aspects it underpins. 
Table 1. Availability of Quaternary prevention concepts on-line for teaching and bibliographic retrieval in various languages. (Direct access by clicking on the link).

\begin{tabular}{|c|c|c|c|}
\hline Languages Types & Types & Purpose & Internet link \\
\hline $\begin{array}{l}\text { English, French, Turkish, Spanish, } \\
\text { Portuguese, Korean, Italian, Vietnamese, } \\
\text { Polish, Dutch, Georgian, Ukrainian }\end{array}$ & HeTOP.eu descriptors & $\begin{array}{l}\text { Teaching \& bibliographic } \\
\text { searches }\end{array}$ & $\begin{array}{l}\text { D2IM Rouen, France } \\
\text { www.hetop.eu/3CGP }\end{array}$ \\
\hline Spanish, Portuguese, English, French & DeCS descriptors & bibliographic searches & $\begin{array}{l}\text { PAHO-WHO Sao Paulo, Brazil } \\
\text { http://decs.bvs.br }\end{array}$ \\
\hline $\begin{array}{l}\text { Chinese, Thai, Vietnamese, French, } \\
\text { Spanish, Portuguese, Dutch, English }\end{array}$ & $\begin{array}{l}\text { Posters on the WICC Web } \\
\text { site }\end{array}$ & Teaching & $\begin{array}{l}\text { WICC WONCA } \\
\text { http://www.ph3c.org/P4 }\end{array}$ \\
\hline Spanish, English, French & $\begin{array}{l}\text { Quaternary Prevention } \\
\text { Library and Resources }\end{array}$ & QP Resource Repository & $\begin{array}{l}\text { QP SIG WONCA } \\
\text { https://goo.gl/oy1gFZ }\end{array}$ \\
\hline
\end{tabular}

\section{Quaternary Prevention and medical ethics}

The definition of Quaternary prevention (QP) reproduced in the Figure 2 ends by the words 'ethically acceptable'. This last phrase of the definition means that the final goal of QP would make clinical practices conduct under bioethical principles. ${ }^{28,29}$ Nowadays, four principles of medical ethics such as non-maleficence, beneficence, respect for autonomy, and justice have been suggested by the Belmont Report ${ }^{30}$ in 1979 and Gillon $^{31}$ in 1994.

- $\quad$ First, the QP has preferentially highlighted the principle of non-maleficence (primum non nocere) ) $^{32}$ by avoiding over-medication. ${ }^{33-35}$ Because clinicians have ethical obligation to protect patients from potential harm. ${ }^{36}$ Especially general practitioners or family physicians (GP/FP) usually are in position to the starting point of clinical management so that they play the important role of preven- ting the cascade of unnecessary medical services. ${ }^{24,37}$ In this context, the responsibility of medical professionalism is stressed in implementing QP. ${ }^{38}$

- Second, beneficence is aimed to provide net medical benefit over harm to patients. ${ }^{31}$ To do this, GP/FP have to achieve evidence-based practice with assessing probabilities of various benefits and harms ${ }^{29,39}$ As Sackett ${ }^{40}$ redefined evidence-based medicine (EBM) as the integration of best research evidence with clinical expertise and patient values, GP/FP have to accept the value-based medicine (VBM). ${ }^{41}$

- Because the definition of VBM by Brown, Brown et Sharma ${ }^{42}$ is 'the practice of medicine incorporating the highest level of evidence-based data with the patient-perceived value conferred by health-care interventions for the resources expended'.

- Third, respect for autonomy gives emphasis to participate patients in a clinical decision-making. ${ }^{31}$ To do this, the concept of 'shared decision making' (SDM) has been stressed. ${ }^{32}$ Especially, SDM would make patients empower, which is a goal of QP, ${ }^{43}$ because Charles et al. described SDM as 'a two-way exchanges of information between the parties concerned with the medical decision'. ${ }^{44}$ Accordingly, Widmer ${ }^{45}$ suggested QP as 'relationship based medicine'. In addition, SDM could overcome a defensive medicine caused by the non-avoidable uncertainty in process of decision making, ${ }^{46,47}$ so that over-diagnosis and over-treatment by medical futility decision could be prevented. ${ }^{41}$ For good communication in clinical setting, GP/FP should consider actively to apply some tools as likely as patient decision aids. ${ }^{49}$ 
- Last, Gillon ${ }^{31}$ distributive justice means to allocate limited health-care resources fairly. Thus, effort to prevent overmedication in QP is following not only the principle of non-maleficence but also the obligation of justice because it could reduce to waste the resources. ${ }^{45}$ In order to avoid in-efficiency of medical services, appropriateness of patients' care should be maintained in individual level. ${ }^{50}$ And the process of setting priorities in health care reflected a social value in population level would be helpful, too. ${ }^{51}$

In summary, implementing the QP is following 4 major principles of medical ethics. Kalra, Baruah et Sahay ${ }^{52}$ suggested 3 aims of QP such as to prevent overmedicalization, to protection from medical invasion, and to suggest ethically acceptable interventions. To achieve these aims under 'being ethically acceptable', GP/PF should get potentialities for medical professionalism, EBM and VBM, SDM, and appropriateness of care.

\section{To teach and learn Quaternary Prevention}

\section{Why should quaternary prevention be taught?}

Three major arguments encourage us to propose to include the subject of quaternary prevention in the training programs of health professionals:

- The first follows from what was discussed in the previous section. Health professionals must learn to behave ethically. Quaternary prevention is a corollary of the four main principles of medical ethics. This implies that health professionals should learn to practice it.

- The second argument is epidemiological. Unexpected damage, caused by health care, is common and in some cases can have very serious consequences for morbidity and mortality. Thus, undergraduate and graduate programs focusing on quaternary prevention should include teaching of key factors, mechanisms and interventions to reduce health care harm.

- The third argument is openness to critical thinking. In our experience, teaching quaternary prevention gives students a different perspective on health practice, especially when the curricula are based on a biomedical model.

The teaching of quaternary prevention illustrates how psychological, social, political and economic forces influence the practice of health.

\section{Which topics should be included?}

The teaching of quaternary prevention is a complex field where epidemiology, communication, doctor-patient relationship, learning-centered approach, teaching skills centered on persons along with many others abilities must be present in a balanced way. Biopsychosocial approach, macro and micro views of different areas such as economy, health care services organization and technological incorporation policies are integral part of QP. In the same way, public and to health professionals other than doctors have to become involved. ${ }^{21}$

After seeing Figure 2, students can, for example, discuss why some people get sick without having a defined illness. Students can also analyze the systems as the Polish example described above 
where politicians dictate mandatory preventive interventions, many of which are not supported by solid evidence. ${ }^{19,20,53}$ A final example would be to discuss the consequences of the progressive lowering of hypertension thresholds in terms of the number of people who are offered pharmacological treatment.

Teaching should also pay attention to the application of quaternary prevention at different organizational levels: the patient-physician relationship (micro), health education and continuing medical education (meso) and at the societal level (macro). Table 2 recently used in a training course in the Family and Community Residence Program in Argentina ${ }^{54}$ shows the complexity of the learning-teaching process that applies quaternary prevention to curricula.

Table 2. Quaternary prevention education according to the levels of organization (adapted from M. Pizzanelli)

\begin{tabular}{|c|c|c|c|c|}
\hline Fields & Ethics & Education & Research & Health Policy \\
\hline $\begin{array}{l}\text { Micro } \\
\text { (Individual) }\end{array}$ & $\begin{array}{l}\text { - empathy } \\
\text { - Self control } \\
\text { - Shared medical decision } \\
\text { making }\end{array}$ & $\begin{array}{l}\text { - Ability to critical reading } \\
\text { - Refusal of market influence }\end{array}$ & $\begin{array}{l}\text { - Self-observation protocol } \\
\text { - Consultation as Qualitative } \\
\text { Research }\end{array}$ & $\begin{array}{l}\text { - Developing a Sociological } \\
\text { Consciousness }\end{array}$ \\
\hline $\begin{array}{l}\text { Meso } \\
\text { (groupe) }\end{array}$ & $\begin{array}{l}\text { - Accurate information } \\
\text { exchange with the group } \\
\text { - Mastering communication } \\
\text { at the group level }\end{array}$ & $\begin{array}{l}\text { - Evidence Based Medicine } \\
\text { - Community health } \\
\text { - Comprehensiveness }\end{array}$ & $\begin{array}{l}\text { - Error control propotocol } \\
\text { - Implementation of the } \\
\text { quality loop }\end{array}$ & $\begin{array}{l}\text { - Supporting a care } \\
\text { integration policy } \\
\text { - Network focused on patient } \\
\text { relations }\end{array}$ \\
\hline $\begin{array}{l}\text { Macro } \\
\text { (society) }\end{array}$ & $\begin{array}{l}\text { - Promotion of horizontal } \\
\text { programs and longitudinality } \\
\text { - Control of the respect of } \\
\text { the rules of confidentiality }\end{array}$ & $\begin{array}{l}\text { - To provide the necessary } \\
\text { tools and database } \\
\text { - Train the actors }\end{array}$ & $\begin{array}{l}\text { - Incitement to } \\
\text { people-centered research } \\
\text { - Take into account the result } \\
\text { of research }\end{array}$ & $\begin{array}{l}\text { - Define a patient-centered } \\
\text { health policy } \\
\text { - Protecting health actors } \\
\text { against market aggression }\end{array}$ \\
\hline
\end{tabular}

Despite this complexity, important wor has already been done on the inclusion of quaternary prevention in the academic agenda. Experts from several Ibero-American countries have issued a series of recommendations on teaching and learning ${ }^{23}$ Graduate trainees should learn how to critically evaluate literature, how to deal with ethical dilemmas, how communicate effectively with patients and promote patient-centered care and shared decision-making. Universities and residency programs should make quaternary prevention a subject of pre- and post-graduate medical education; train medical teachers in quaternary prevention, support residents who want to do research on quaternary prevention and include it in pre-graduation and undergraduate exams.

As stated in the introduction, quaternary prevention is based on relationship. However, the lack of lasting and meaningful relationships with patients, supervisors, peers and professional colleagues, caused by the current structure of medical education in some countries, results in a weak capacity to build relationships in the future. Students and residents should develop relationships with patients and team members to enable feedback. In a qualitative study, residents described how frequent transitions from one service to another affected their ability to create relationships with patients. ${ }^{55}$ In integrated longitudinal training, students have the opportunity to develop one-year relationships with faculty and patients. Hirsch and all. ${ }^{56}$ demonstrated that students perceive their relationships with patients as having a real impact on the well-being of patients, more than in a comparison group. Students also had better empathy scores at the end of the Integrated Longitudinal Training Program than did students in a traditional program. 


\section{What results can we expect from teaching quaternary prevention?}

Few published studies evaluate the impact of quaternary prevention education. We found an intervention study of fifth-year medical students at Pham Ngoc Thach University (Hochiminh City, Vietnam). ${ }^{55}$ Students were asked to list their potential interventions based on three different simulated clinical scenarios before and after the Quaternary Prevention training intervention.

Despite the brevity of the intervention, the survey showed changes in students' attitudes about clinical decisions. This means that the framework of quaternary prevention could change the clinical reasoning and decisions of medical students. ${ }^{23}$

The introduction of the reasoning framework to quaternary prevention could stimulate medical students in a holistic reasoning process (whole person care), which is one of the principles of family medicine. Students could also become more independent researchers by acquiring cognitive skills that allow them to analyze relevant information about medical interventions based on the needs of patients. These results of the study suggest a positive change in behavior in the student decision-making process. ${ }^{23}$

In summary, there are strong theoretical arguments for including quaternary prevention in a renewed curriculum focused on the first and second cycle.

\section{Anthropological dimensions of Quaternary Prevention}

Originally quaternary Prevention find a first solution to overmedicalisation with an increased attention on psychological ${ }^{57}$ and social dimensions of health, ${ }^{58}$ according the bio-psycho-social model. ${ }^{59}$ It became evident that overmedicalisation can affect all domains of medicine (primary, secondary and tertiary prevention are also involved). ${ }^{18}$

Evidence Based Medicine (EBM) is certainly the essential instrument to assess a medical technology. We use here the term health technology in the broad sense of European Commission ${ }^{60}$ as "comprising medicinal products, a medical device or medical and surgical procedures as well as measures for disease prevention, diagnosis or treatment used in healthcare".

All medical technologies can be most often submitted to EBM procedures, necessary to evaluate their utility or their danger.

Can all the medical activity be reduced to a health technology submitted to evidence based evaluations? Sackett et al. ${ }^{61}$ admitted that clinical expertise was fundamental beside best clinical evidence. We know that general practitioners cannot apply every time and everywhere best clinical evidence but that outcomes of treatment in general practice are better than those of the sum of specialists applying separately evidence of their own domain. This fact is known as "paradox of primary care", ${ }^{2}$ confirming the importance of clinical expertise, weighting evidence for each clinical, psychological and social situation. Some voices have call not to reduce evidence to the dominance of measures and randomized controlled trials, but to integrate qualitative research in the process, mixed method becoming a new model for scientific research in medicine..$^{4,63}$

Social and cultural anthropology interested in medicine and health shares, through its rigorous ethnographic approach ${ }^{64}$ - including participant observations, interviews, focus groups, as well as its concepts and theories -, a critical reading in different fields contributing to quaternary prevention by: 
- An interest in clinical practice, to be regarded as a social space confronted to a set of norms and values, social and professional models, as well as political and economic implications. ${ }^{65}$

- Inventory of clinical experience. How GPs really do for avoiding overmedicalisation? How they decide in uncertainty? ${ }^{2,66}$ How they use new technologies?

- Anthropological field surveys in certain areas, for example migrants, rural remote areas, to understand patient's representations and behaviour, care pathways, individual and community priorities, organization of care facilities ${ }^{67}$ and availability of cultural simple and efficient solutions. ${ }^{68}$ Qualitative approach and ethnographic analysis can also be a mode of practices evaluation, taking into account barriers, inappropriate approaches and point of view of people.

- Interest for political discussions about regulation and assessment of health technologies to understand the ways of decisions, the role of stakeholders and factors contributing to assessment other than evidence, such as ethical or socio-political matters. Quaternary prevention approach seems particularly important in context where health technologies are developed and available.

- Interest for global health, with the aim to connect society with health innovations and health policies/health delivery, and thus to analyze health transformations within local-global relations, between the universality of scientific medicine and its social and cultural background. This stance ought to be all the more critical due to the fact that the transformations carried by the globalization of healthcare often form an asymmetrical, unequal and differentiated process, regarding the implementation of programs as well as the circulation of models. ${ }^{69}$

In that respect, and in a quaternary prevention context, an anthropological approach addresses the ethical issues related to clinical practice, which can be analyzed according to different dimensions: global health, national policies, corporate cultures, clinical and care practices, and patients' experiences.

\section{Socio-politics implication of Quaternary prevention}

Family Medicine emerged as a response to a medical care that became fragmented, depersonalized and discontinuous. The Quaternary prevention concept challenges the positivist ideals of modernity that maintain that science and the progress of society are constant and always for the better.

This conception refers us to the idea of positive iatrogenia of Michael Foucault when reminding us that medicine has acquired the capacity to harm due to its correct exercise and not only due to lack of skill or ignorance. ${ }^{16}$ Moving away from the conception of science of modernity allows us to separate ourselves from the idea that science is something that only deals with knowledge and is divorced from ethics and the influences of politics and economics, in short, the P4 challenges the inadequacies of the Hegemonic Medical Model. ${ }^{70}$

Medicine has been in crisis for a long time. The signs of the inadequacy of the answers offered by this model of medicine are the growing dissatisfaction of the population and of the professionals. Medical care has become fragmented, depersonalized and discontinuous, with increasing costs, with a festival of technology and molecules of doubtful utility, increased conflicts between patients and the health team, and the feeling of helplessness, low valuation of their task and defensive attitude of doctors towards patients and the worrying increase in the judicialization of conflicts. It is also a sign the proliferation of alternative 
medicines, shamans, magic solutions and charlatans to which people go at the same time as official medicine in a kind of utilitarian syncretism that denounces the lack of confidence in the model.

Health is a fundamental right of the human being and, Health Systems and many governments, are not guaranteeing it. As a result of this, a reform of the Health Systems has been demanded for a long time, but the attempts of change have been based on economist based ideas limited to the health sector, so they have not been successful in achieving equity, accessibility and justice, that must characterize a Health System and, in many cases, these reforms have only aggravated the situation.

Any reform of a Health System must be initiated from an ethical perspective, with clearly formulated political principles and must include the Society as a whole to achieve a sustainable change. Any reform of a Health System must consider and include the political and economic aspects inherent in the field of health.

Quaternary prevention began as a response to the excesses of medicalization, disease mongering, the transformation of risk factors into diseases, overdiagnosis, etc. The search was oriented from a scientific perspective but, after thirty years, we see that these arguments, although solid and necessary, are not enough because the nature of the dispute is different, it is economic and political.

Quaternary prevention has understood that deep causes far exceed the limits of medicine, has understood that the problem includes ethical, political, economical and conceptual views of science and medicine. It is for this reason that the definition of Quaternary prevention has overcome the initial definition centered on a biomedical vision. Quaternary prevention has understood that a new model of medicine and a new pact with society is necessary.

Quaternary prevention is a movement that promotes a change in the way of being and practice medicine starting with the ethical and philosophical aspects in order to protect patients and members of the health team from the excesses of medicalization and the excessive desire of profit of some actors.

In that sense, in the Declaration of $\mathrm{Rio}^{21}$ we have postulated a model characterized by being:

- Inclusive

- Non-reductionist, integral and integrated.

- That tolerates uncertainty.

- That it implies the human, social and political dimensions.

- To avoid and denounce the naturalization of: hunger, exclusion, manipulation, inequality, violence, racism, exploitation, which harms health more than diseases.

Quaternary prevention is a movement ${ }^{26}$ that seeks to refund the ethical values of medicine so that it becomes an activity for humans exerted by humans and in contact with life. The quaternary prevention does not intend certainties. There is no safe arrival point, there is no predetermined route, there are no guarantees, the only thing we know is that we are building utopias.

\section{References}

1. Lévy E. Ilya Prigogine «L'incertitude, c'est la vie»: lepoint.fr; 2002/01/18 [Available from: http://www.lepoint.fr/actualiteschroniques/2007-01-20/ilya-prigogine-l-incertitude-c-est-la-vie/989/0/60025.

2. Bloy G. L'incertitude en médecine générale: sources, formes et accommodements possibles. Sciences sociales et santé. 2008;26(1):67-91.

3. Davidoff F, Haynes B, Sackett D, Smith R. Evidence based medicine. BMJ. 1995. 
Ethical, pedagogical, socio-political and anthropological implications of quaternary prevention

4. Greenhalgh T, Howick J, Maskrey N. Evidence based medicine: a movement in crisis? Bmj. 2014;348:g3725.

5. Clark EG. Natural history of syphilis and levels of prevention. British Journal of Venereal Diseases. 1954;30(4):191.

6. Bury J. Éducation pour la santé: concepts enjeux planifications. 1988.

7. Gofrit ON, Shemer J, Leibovici D, Modan B, Shapira SC. Quarternary prevention: a new look at an old challenge. Isr Med Assoc J. 2000;2:498-500.

8. Bentzen N. WONCA Dictionary of General/Family Practice. Copenhagen: Maanedsskr; 2003.

9. Jamoulle M. Information et informatisation en médecine générale [Computer and computerisation in general practice]. Namur, Belgium: Presses Universitaires de Namur; 1986.

10. Jamoulle M. Quaternary prevention, an answer of family doctors to overmedicalization. Int J Health Policy Manag. 2015;4(2):61-4.

11. Hellstrom OW. Health promotion in general practice. Eur J Public Health. 1994;4:119-24.

12. Sadegh-Zadeh K. Anamnesis and diagnosis. In: Sadegh-Zadeh K, editor. Handbook of Analytic Philosophy of Medicine. Dordrecht: Springer; 2015. p. 363.

13. Carpentier J. Medical Flipper. Cahiers libres, 402. 1989:154.

14. UEMO. UEMO position on Disease Mongering/Quaternary Prevention 2008 [Available from: http://www.uemo.eu/2011/02/08/uemoposition-on-disease-mongering-quaternary-prevention/

15. Jamoulle M, Tsoi G, Heath I, Mangin D, Pezeshki M, Pizzanelli Báez M, editors. Quaternary prevention, addressing the limits of medical practice. WONCA World; 2013 2013; Prague.

16. Foucault M. La crisis de la medicina o la crisis de la antimedicina. 1974. Revista Cubana de Salud Pública. 2018;44:172-83.

17. Brownlee S. Overtreated: Why too much medicine is making us sicker and poorer: Bloomsbury New York; 2007.

18. Martins C, Godycki-Cwirko M, Heleno B, Brodersen J. Quaternary prevention: reviewing the concept: Quaternary prevention aims to protect patients from medical harm. European Journal of General Practice. 2018;24(1):106-11.

19. Sagan A, Panteli D, Borkowski W, Dmowski M, Domanski F, Czyzewski M, et al. Poland health system review. Health Systems in Transition. 2011;13(8):1-193.

20. Godycki-Ćwirko M, Krawczyk J, Tomiak E, Osiecka R, Mazurek L, Ludwikow G, et al. Czasochłonność profilaktyki w podstawowej opiece zdrowotnej [Time requirements for prevention in primary health care]. Probl Med Rodz. 2009;1(26):23-7.

21. Wonca Special Interest Group on Quaternary Prevention and Overmedicalisation. Manifeste; La Prévention quaternaire, présent et futur Proclamation de Rio de Janeiro. Décembre 2016 [Available from: http://www.ph3c.org/PH3C/docs/27/000449/0000842.pdf.

22. WONCA Special Interest Group: Quaternary Prevention \& Overmedicalization 2017 [Available from: http://www.globalfamilydoctor.com/ groups/SpeciallnterestGroups/QuaternaryPrevention.aspx.

23. Gomes LF, Gusso G, Jamoulle M. Teaching and learning quaternary prevention. Revista Brasileira de Medicina de Família e Comunidade. 2015;10(35):1-14.

24. Alber K, Kuehlein T, Schedlbauer A, Schaffer S. Medical overuse and quaternary prevention in primary care-A qualitative study with general practitioners. BMC family practice. 2017;18(1):99.

25. Franken G. Prävention und Demenz Eine Begriffsklärung Literaturstudie. Witten: Universität Witten/ Herdecke (Arbeitspapier des DZD, 12). Dialog- und Transferzentrum Demenz (DZD); 2016.

26. La Valle RA. Prevención Cuaternaria o la Medicina sin corbata. Archivos de Medicina Familiar y General. 2015;12:5-6.

27. Brodersen J, Schwartz LM, Woloshin S. Overdiagnosis: how cancer screening can turn indolent pathology into illness. Apmis. 2014;122(8):683-9.

28. Martínez CG, Riaño IG, Sánchez MJ, de Dios González J, editors. Quaternary prevention: Containment as an ethical necessity. Anales de pediatria (Barcelona, Spain: 2003); 2014.

29. Tesser CD. Why is quaternary prevention important in prevention? Revista de saude publica. 2017;51:116.

30. Department of Health E. The Belmont Report. Ethical principles and guidelines for the protection of human subjects of research. The Journal of the American College of Dentists. 2014;81(3):4.

31. Gillon R. Medical ethics: four principles plus attention to scope. BMJ: British Medical Journal. 1994;309(6948):184. 
32. Bae J-M. Shared decision making: relevant concepts and facilitating strategies. Epidemiology and health. $2017 ; 39$.

33. Smith CM. Origin and uses of primum non nocere-above all, do no harm! The Journal of Clinical Pharmacology. 2005;45(4):371-7.

34. Visentin G. The difficult choice of" not doing": comment on" Quaternary prevention, an answer of family doctors to overmedicalization". International journal of health policy and management. 2015;4(8):559.

35. Bae J-M, Jamoulle M. Primary care physicians' action plans for responding to results of screening tests based on the concept of quaternary prevention. Journal of Preventive Medicine and Public Health. 2016;49(6):343.

36. Gérvas J, Starfield B, Heath I. Is clinical prevention better than cure? The Lancet. 2008;372(9654):1997-9.

37. Deyo RA. Cascade effects of medical technology. Annual review of public health. 2002;23(1):23-44.

38. Medicine AFABol. ACP-ASIM Foundation. American College of Physicians-American Society of Internal Medicine; European Federation of Internal Medicine. Medical professionalism in the new millennium: a physician charter. Ann Intern Med. 2002;136(3):243-6.

39. Bae J-M. Suggestions for the promotion of evidence-based public health in South Korea. Epidemiology and health. $2017 ; 39$.

40. Sackett DL. Evidence-based Medicine How to practice and teach EBM: WB Saunders Company; 1997.

41. Bae J-M. Value-based medicine: concepts and application. Epidemiology and health. 2015;37.

42. Brown GC, Brown MM, Sharma S. Health care economic analyses. Retina. 2004;24(1):139-46.

43. Jamoulle M. A Comment on “Quaternary Prevention in Public Health” by Dr. Jong-Myon Bae. J Prev Med Public Health. 2016;49(2):13940.

44. Charles C, Gafni A, Whelan T. Shared decision-making in the medical encounter: what does it mean?(or it takes at least two to tango). Social science \& medicine. 1997;44(5):681-92.

45. Widmer D. Care and do not harm: Possible misunderstandings with quaternary prevention (P4): comment on "Quaternary prevention, an answer of family doctors to over medicalization”. International journal of health policy and management. 2015;4(8):561.

46. Premji K, Upshur R, Légaré F, Pottie K. Future of family medicine: Role of patient-centred care and evidence-based medicine. Canadian Family Physician. 2014;60(5):409-12.

47. Malin JL. Wrestling with the high price of cancer care: should we control costs by individuals' ability to pay or society's willingness to pay?: American Society of Clinical Oncology; 2010.

48. Swanson JW, Van McCrary S. Medical futility decisions and physicians' legal defensiveness: the impact of anticipated conflict on thresholds for end-of-life treatment. Social Science \& Medicine. 1996;42(1):125-32.

49. Bae J-M. Development and application of patient decision aids. Epidemiology and health. 2015;37.

50. Bae J-M. Strategies for Appropriate Patient-centered Care to Decrease the Nationwide Cost of Cancers in Korea. Journal of Preventive Medicine and Public Health. 2017;50(4):217.

51. Starfield B, Hyde J, Gérvas J, Heath I. The concept of prevention: a good idea gone astray? Journal of Epidemiology \& Community Health. 2008;62(7):580-3.

52. Kalra S, Baruah MP, Sahay R. Quaternary prevention in thyroidology. Thyroid Research and Practice. 2014;11(2):43.

53. Godycki-Ćwirko M, Tomiak E, Wrzeciono B, Lukas W. Zakres profilaktyki w podstawowej opiece zdrowotnej [Scope of prevention in primary care]. Problemy Medycyny Rodzinnej. 2009;11(1):15-22.

54. Bentaberry M, Bernstein J, Jamoulle M, La Valle R, Mariño MA, Piñero A, et al. Curso Introductorio a la Práctica de la Prevención Cuaternaria (P4) SUMEFAC \& FAMFyG 2017 [Available from: http://www.famg.org.ar/archivos/Version-Imprimible-Curso-Introducciona-la-Practica-de-la\%20-Prevencion-Cuaternaria\%20(P4).pdf.

55. Tran THV, Vo TL. Impact of quaternary prevention as a brief intervention in medical students' clinical decisions: experience from Vietnam Impacto da prevenção quaternária como intervenção breve nas decisões clínicas de estudantes de medicina: In the last decades medica. Revista Brasileira de Medicina de Família e Comunidade. 2015;10:1-8.

56. Hirsch CD, Barlem ELD, Barlem JGT, Dalmolin GdL, Pereira LA, Ferreira AG. Cross-cultural adaptation and validation of the Nursing Student Satisfaction Scale for use with Brazilian nursing students. Revista latino-americana de enfermagem. $2016 ; 24$.

57. Balint M. The doctor, his patient, and the illness. The Lancet. 1955;265(6866):683-8.

58. Illich I. Medical nemesis: The expropriation of health. New York: Pantheon Books; 1976. 
59. Engel GL. The need for a new medical model: a challenge for biomedicine. Science. 1977;196(4286):129-36.

60. Commission E. Proposal for a regulation of the European Parliament and of the Councilon health technology assessment and amending Directive 2011/24/EUBrussels: European commission; 31.1.2018.

61. Sackett DL, Rosenberg WM, Gray JM, Haynes RB, Richardson WS. Evidence based medicine: what it is and what it isn't. British Medical Journal Publishing Group; 1996.

62. Stange KC, Ferrer RL. The paradox of primary care. Annals of Family Medicine. 2009;7(4):293-9.

63. Pluye P, Hong QN. Combining the power of stories and the power of numbers: mixed methods research and mixed studies reviews. Annual review of public health. 2014;35.

64. Olivier de Sardan J-P. La rigueur du qualitatif. Les contraintes empiriques de l'interprétation socio-anthropologique. Lectures, Publications reçues. 2008.

65. Rossi I. La clínica como espacio social ¿Época de cambios o cambio de época? In: Sutton LHM, Torres A, Hernández I, editors. La comunicación dialógica como competencia médica esencial. Mexico: Editorial El Manual Moderno; 2017. p. 38-57.

66. Toon P. Books: Mapping Uncertainty in Medicine: What to Do When You Don't Know What to Do: Mapping the Terrain. British Journal of General Practice; 2016

67. Kumar NS. Health situation of scheduled castes in Bolpur-Sriniketan. Anthropological Survey of India. Kolkata: Ministry of Culture; 2011.

68. Chaudhuri B. Health for All: Looking for an Alternative Approach. Dr Ambedkar Chair in Anthropology. Department of Anthropology, Calcutta University; 2008.

69. Farmer P, Kim JY, Kleinman A, Basilico M. Reimagining global health: an introduction: Univ of California Press; 2013.

70. Menendez EL. El modelo médico y la salud de los trabajadores. Salud colectiva. 2005;1:9-32. 